\title{
40. LATE MIOCENE-QUATERNARY CALCAREOUS NANNOFOSSIL BIOMAGNETOCHRONOLOGY ON THE EXMOUTH PLATEAU, NORTHWEST AUSTRALIA ${ }^{1}$
}

\author{
William G. Siesser, ${ }^{2}$ Timothy J. Bralower,${ }^{3}$ Cheng Tang, ${ }^{4}$ and Bruno Galbrun ${ }^{5}$
}

\begin{abstract}
Drilling on the Exmouth Plateau during Ocean Drilling Program Leg 122 recovered an almost complete Cenozoic sequence at Site 762. Sediments at this site contain abundant, diverse, and generally well-preserved calcareous nannofossils. The continuity of the stratigraphic sequence, preservation of the taxa, and availability of magnetostratigraphy offered an opportunity to construct a first-order biomagnetochronologic history for late MioceneQuaternary calcareous nannofossils at Site 762. Magnetochronologically dated FADs/LADs for 23 different nannofossils are given in this study. FADs or LADs for five of these species (Discoaster blackstockae, D. calcaris, Rhabdosphaera claviger, $R$. longistylis, and $R$. procera) have never been presented before. In addition, a LAD for Ceratolithus rugosus is new. We believe these new age datums, and the complementary information on previous datums, will add to the growing refinement of Cenozoic biomagnetochronology.
\end{abstract}

\section{INTRODUCTION}

Biochronology has been defined as the organization of geologic time according to the irreversible process of organic evolution (Berggren and van Couvering, 1978). Biochronology differs from biostratigraphy in that biostratigraphy deals solely with the organization of rock strata into units (biozones) based on their fossil content. A biozone is present only within the occurrence limits of the fossils on which the biozone is based. Biostratigraphy allows a stacking of relatively older and younger biozones, but gives no information about the absolute age (in terms of years) of the biozones.

Biochronology refers to the accurate dating of the evolutionary first occurrences or extinctions of species, using ages calculated by radiometric methods alone, or by interpolation between radiometrically calibrated magnetic reversals (biomagnetochronology). These dated levels will be referred to here as first appearance datums (FADs) and last appearance datums (LADs). Because many of the biostratigraphic first occurrences (FOs) and last occurrences (LOs) serve as the boundaries of biostratigraphic interval zones, the ages of the FADs/LADs also date the zonal boundaries used in biostratigraphic schemes. Thus the combination of biostratigraphy and magnetochronology has enabled the development of a refined method usable for regional and global correlation and age assignment.

Biomagnetochronology is most reliable when it is based on cores or stratigraphic sections where both biostratigraphic identifications and magnetostratigraphic measurements can be performed on the same samples (i.e., first-order correlations). Organisms such as calcareous nannofossils are excellent biostratigraphic markers because of their great abundance in

\footnotetext{
${ }^{1}$ von Rad, U., Haq, B. U., et al., 1992. Proc. ODP, Sci. Results, 122: College Station, TX (Ocean Drilling Program).

${ }^{2}$ Department of Geology, Vanderbilt University, Nashville, TN 37235 , U.S.A.

${ }^{3}$ Department of Geology, Florida International University, Miami, FL 33199, U.S.A. (Current address: Department of Geology, University of North Carolina, Chapel Hill, NC 27599, U.S.A.)

${ }^{4}$ Earth Science Board, University of California, Santa Cruz, Santa Cruz, CA 95064, U.S.A.

5 Université Paris VI, Département de Géologie Sédimentaire, UA-CNRS 1315, 4 place Jussieu, 75252 Paris Cedex 05, France.
}

marine sediments, rapid evolution, and planktonic mode of life. First-order correlations of many nannofossil FOs and LOs to the magnetostratigraphic time scale have been available for some time for the upper Miocene to Holocene interval, largely based on investigations of piston cores (e.g., Gartner, 1973; Ryan et al., 1974; Haq et al., 1977). Most of the pre-upper Miocene sediments obtained during early legs of the Deep Sea Drilling Project were cored by rotary drilling methods, however, and were either too badly disturbed or poorly recovered for accurate magnetostratigraphic work. With the advent of the hydraulic piston corer (HPC), and later the advanced piston corer (APC), relatively undisturbed cores allowed first-order correlation of nannofossil and foraminiferal events to magnetostratigraphy in pre-upper Miocene deep-sea sediments (e.g., Hsü et al., 1984; Poore et al., 1984).

Drilling at Site 762 on the central Exmouth Plateau (Fig. 1) encountered an almost complete Cenozoic section. Preservation of nannofossils and foraminifers is generally goodsometimes excellent-throughout the Cenozoic at this site. The completeness of the Cenozoic section, the high diversity and good preservation of fossil taxa, and the suitability of the upper Miocene-Quaternary sediments for magnetostratigraphic analysis provided an excellent opportunity for assessment of calcareous nannofossil biomagnetochronology for this stratigraphic interval on the Exmouth Plateau.

\section{GEOLOGIC SETTING}

The Exmouth Plateau is a deeply subsided fragment of rifted continental crust lying off the coast of northwestern Australia (Fig. 1). The present configuration of the plateau began to take shape during the Late Triassic, when East Gondwanaland rifting between northwestern Australia, greater India, and other Gondwanan fragments began (Haq, 1988b). Breakup and separation occurred during the JurassicEarly Cretaceous, after which 1-2 km of pelagic and hemipelagic sediments accumulated on the plateau. The JOIDES Resolution drilled at six sites on the Exmouth and Wombat plateaus (the latter being a marginal spur of the former) during Leg 122 (Haq et al., 1988b).

We shall discuss only Site 762 , the site pertinent to this study. Drilling at Site 762 encountered a thick, almost continuous sequence of nannofossil ooze and chalk ranging in age from Quaternary to Maestrichtian. The only parts of the 


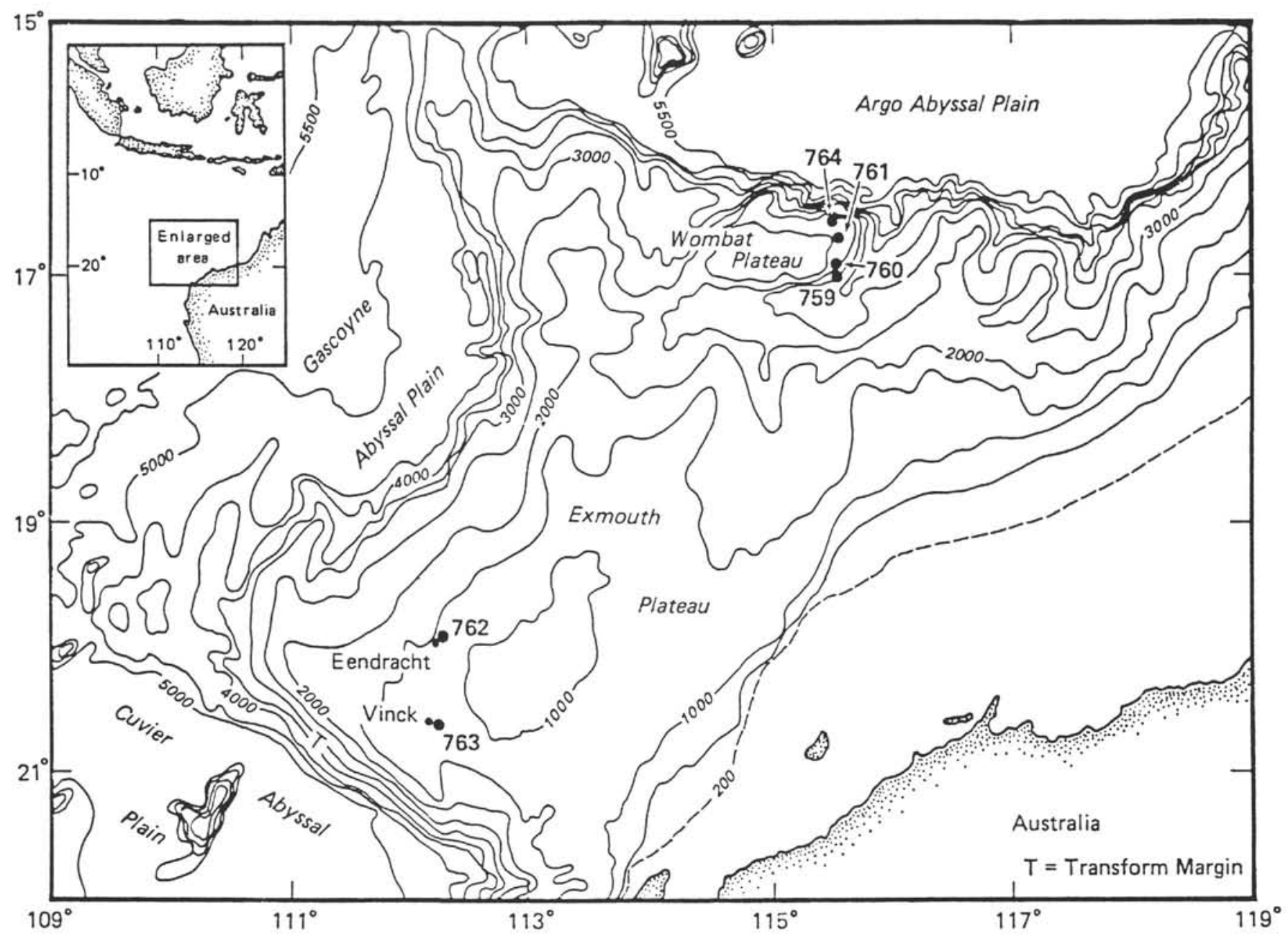

Figure 1. Location map showing Leg 122 drill sites on the central Exmouth Plateau (Sites 762 and 763) and on the Wombat Plateau (Sites 759, 760,761 , and 764). Contours are in meters below sea level. Map is from Haq et al. (1988b).

Cenozoic missing are short intervals in the Miocene (viz., Martini's (1971) nannofossil Zones NN3, NN8, and NN10).

Three holes were drilled at Site 762 (Holes $762 \mathrm{~A}, 762 \mathrm{~B}$, and $762 \mathrm{C}$ ) in a water depth of $1340 \mathrm{~m}$. Hole $762 \mathrm{~A}$ recovered a single core of Quaternary age. Hole 762B was cored using the APC down to a depth of 175.4 meters below sea floor (mbsf) (lower Oligocene).

\section{METHODS}

We examined each Cenozoic core section from Hole 762B in order to document the FOs and LOs of nannofossil species. Tables showing the relative abundance and distribution of species used in this study, together with illustrations of the species, are given in Siesser and Bralower (this volume). Details of taxonomic and biostratigraphic concepts used are also given in that chapter.

We made a determination of the biostratigraphic FO/LO of each species considered in this report. Nannofossil determinations are based on one sample per section. If we disregard potential diagenetic complications, the degree of $\mathrm{FO} / \mathrm{LO}$ stratigraphic accuracy in sequential sections is at least within $75 \mathrm{~cm}$, and sometimes less, since the assumed $\mathrm{FO} / \mathrm{LO}$ position of a given species was placed in the middle of the uninvestigated $1.5-\mathrm{m}$ interval between samples. As an example, if a species was first found at, say, $100 \mathrm{~cm}$ in section 3 of a core, but not at $100 \mathrm{~cm}$ in section 4 , we placed the FO halfway between the two samples examined (i.e., at $25 \mathrm{~cm}$ below the top of section 4). The depth in meters below seafloor of this FO position was then calculated from the depths given on Leg 122 core description forms ("barrel sheets"). In a few cases, an entire section (or sections) of a core is missing (not recovered) above or below an apparent FO/LO. In these circumstances the FO/LO is approximated as being in the middle of the missing interval, in which case the potential stratigraphic error will be greater than for sequential sections.

Magnetostratigraphic analytical techniques, data on the magnetic properties of the sediments, and the results of Miocene-Quaternary polarity measurements in Hole 762B are given in Tang (this volume). Whole-core measurements were supplemented by polarity measurements made on oriented samples collected from each core section. All samples were subjected to alternating-field demagnetization.

"Chron" is the basic working unit of magnetostratigraphy (replacing "Epoch" of earlier schemes). We have followed the definition of Tauxe et al. (1984) in which a chron is defined as the time interval between the youngest reversal boundaries of successively numbered magnetic anomalies. The letter " $C$ "' (chron) is placed before the number of the magnetic anomaly; " $R$ " or " $\mathrm{N}$ " may be added after the number to indicate reversed or normal polarity "subchrons," or intervals within the chron.

Chrons can easily be recognized back to Chron C3A (upper Miocene) on the basis of polarity reversals in Hole 762B (Fig. 2). The earlier Miocene magnetostratigraphic record is less confidently interpreted because of interruption by the three Miocene hiatuses mentioned earlier. Paleogene chronal 


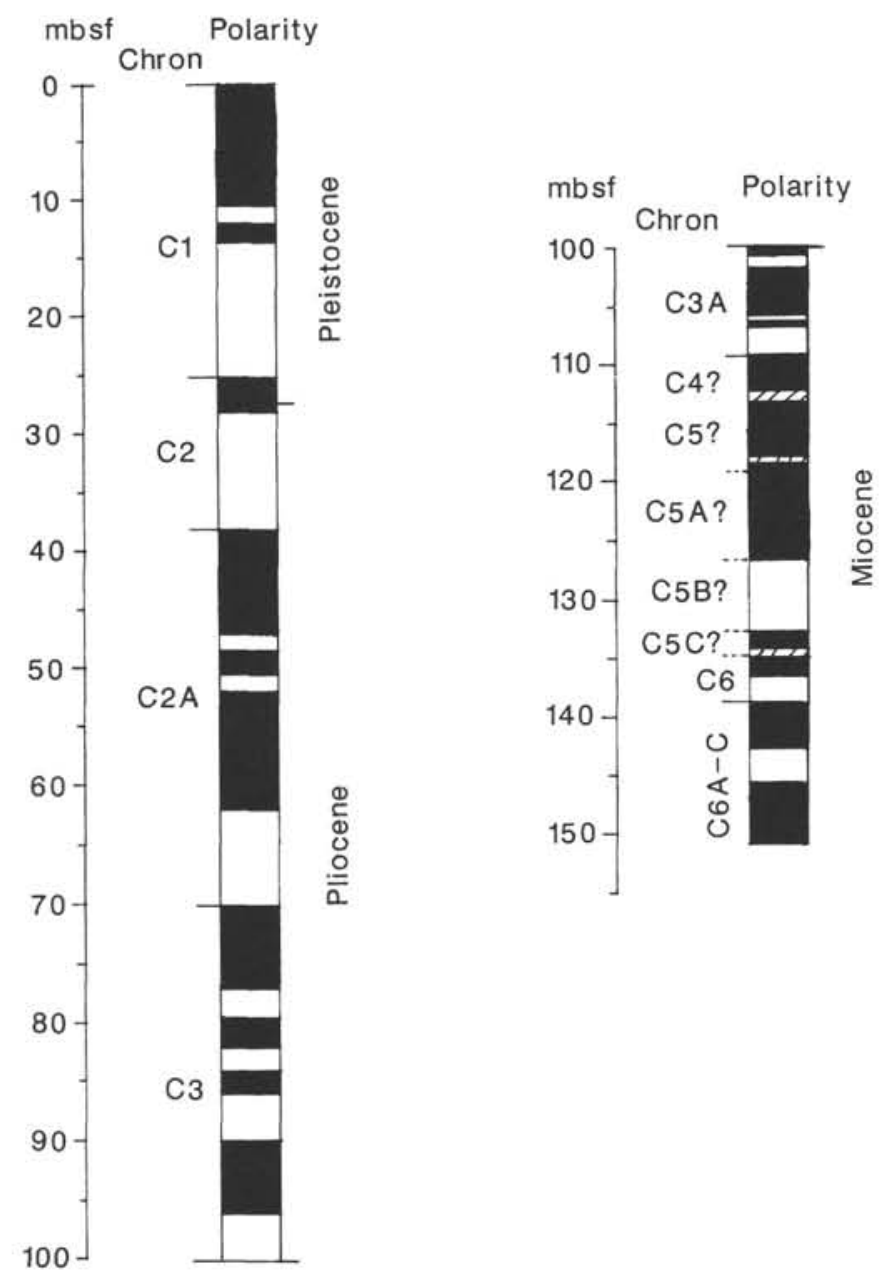

Figure 2. Magnetostratigraphy of Hole 762B for the Miocene-Quaternary interval. Depths are in meters below sea floor (mbsf). Dark areas represent normal polarity; light areas represent reversed polarity. Inclination/declination data are presented in Tang (this volume).

boundaries (Galbrun, this volume, chapter 42) in Holes 762B and $762 \mathrm{C}$ are recognized partly on the basis of polarity reversals and partly on the basis of nannofossil biostratigraphy. For that reason, our biomagnetochronologic study will focus only on Chron $\mathrm{C} 3 \mathrm{~A}$ and younger chrons, where chronal boundaries are assignable by the polarity pattern alone.

We estimated the position of the top of each anomaly (i.e., the upper boundary of each chron) by a procedure similar to the biostratigraphic $\mathrm{FO} / \mathrm{LO}$ approximation. For example, if the last Chron C2A-R sample measured was in section 5 at $123 \mathrm{~cm}$, and the first Chron C3-N sample measured was in section 6 at $81 \mathrm{~cm}$, the top of Chron C3-N would be estimated to be in section 6 at $27 \mathrm{~cm}$. The mbsf of the top of Chron $\mathrm{C} 3-\mathrm{N}$ could then be calculated from depths on barrel sheets. Haq et al. (1988a) have published stacked mean ages for anomaly tops, based on best-fit solutions of radiometric dates. We used these ages for the upper chron boundaries in our study. Assuming a constant sedimentation rate, the age of any point in meters below seafloor within a chron can thus be calculated. Once the depth (mbsf) of each nannofossil FO/LO is known, an age in years for that level (a FAD/LAD) can be calculated using the magnetochronologic age data and time scales of Haq et al. (1987) and Haq et al. (1988a).

\section{BIOMAGNETOCHRONOLOGY}

Nannofossil biomagnetochronology of deep-sea cores continues to be refined, and correlation of nannofossil FOs/LOs to magnetostratigraphy has also been expanded to include onshore marine sediments (e.g., Lowrie et al., 1982; Monechi and Thierstein, 1985; Aubry et al., 1986). FADs and LADs of many important Neogene marker species, and to a lesser extent, Paleogene markers, have now been determined (Backman and Shackleton, 1983; Berggren et al., 1983; Haq, 1984; Haq and Takayama, 1984; Shackleton et al., 1984; see also Berggren et al., 1985a, Berggren et al., 1985b, Hills and Thierstein, 1989; Wei and Wise, 1989, and Weaver et al., 1989, for recent compilations of Cenozoic nannofossil FADs and LADs). Other important contributions to Cenozoic nannofossil biochronology are the studies by Aubry et al. (1988), who described in some detail the components, methods, and sources of error in geochronology, with special reference to the Paleogene, and the work by Dowsett (1989), who evaluated an alternative to conventional biomagnetochronology by constructing a biochronologic model for the Pliocene using graphic correlation. Biomagnetochronology of the large number of "minor" nannofossil species and secondary zonal marker species has, however, received only cursory attention, despite the widespread use of secondary markers in routine biostratigraphy. In normal biostratigraphic investigations, some of the primary marker species used in the standard calcareous nannofossil zonations of Martini (1971) and Bukry (1973, 1975) and Okada and Bukry (1980) are almost always missing, owing to unfavorable environmental conditions or diagenetic alteration. Practicing biostratigraphers are often obliged to modify their use of standard zonations by using secondary markers whose first occurrences/extinctions only approximate those of the primary markers.

It is obviously useful to have a selection of secondary marker species available to approximate the standard zonal boundaries in the absence of the primary markers. Establishing exactly where the first occurrences and last occurrences of these secondary markers occur within standard biozones, and in time, and how closely they approximate the FOs/FADs and $\mathrm{LOs} / \mathrm{LADs}$ of primary markers is of considerable importance.

As mentioned earlier, Site 762 contains an almost complete Cenozoic sequence. In addition, nannofossil preservation in all parts of the Cenozoic is generally good and this has resulted in the preservation of a number of species that are normally removed by solution or obscured by diagenesis. The abundance of nannofossils throughout the section, the degree of preservation, the continuity of the sequence, and the availability of usable magnetostratigraphy on the upper Miocene-Quaternary interval of the same cores offered a valuable opportunity for a detailed biozonation and biomagnetochronologic assessment of several secondary nannofossil appearance/extinction events. These secondary events are currently only poorly dated, if dated at all. Even for the primary Neogene markers, biomagnetochronology is based on only a few studies (see Berggren et al., 1985a; Berggren et al., 1985b; and Hills and Thierstein, 1989), and the results presented here will further test the accuracy of previous assignments.

Table 1 lists the species investigated in this study. We have not used all the late Miocene-Quaternary species from the range charts in Siesser and Bralower (this volume), as some taxa have occurrences that are too rare or sporadic to be biostratigraphically reliable. Table 1 shows the calculated ages in Ma of the FADs/LADs of 23 species in Hole 762B, together with the occurrence depth of the species in meters below seafloor. The position of each species occurrence within a given chron is described further in the Appendix. FADs/LADs for five of these species (Discoaster blackstockae, D. calcaris, $R$ habdosphaera claviger, $R$. longistylis, and $R$. procera) have never been presented before. In addition, an LAD for Ceratolithus rugosus has not been previously published. Earlier published ages for nannofossil FADs/LADs have been compiled and summarized from a large number of sources by 
Table 1. Calcareous nannofossil biomagnetochronology on the Exmouth Plateau.

\begin{tabular}{|c|c|c|c|c|}
\hline & $\begin{array}{l}\text { Depth } \\
\text { (mbsf) }\end{array}$ & $\begin{array}{l}\text { FAD } \\
\text { (Ma) }\end{array}$ & $\begin{array}{l}\text { Depth } \\
\text { (mbsf) }\end{array}$ & $\begin{array}{l}\text { LAD } \\
\text { (Ma) }\end{array}$ \\
\hline Sphenolithus abies/S. neoabies & - & 57.4 & 3.4 & \\
\hline Ceratolithus acutus & 99.9 & 5.4 & 88.7 & 4.8 \\
\hline Amaurolithus amplificus & 109.4 & 6.7 & 93.2 & 5.1 \\
\hline Discoaster asymmetricus & 71.4 & 4.0 & - & - \\
\hline Discoaster blackstockae & 106.6 & 6.3 & 98.9 & 5.4 \\
\hline Discoaster brouweri & - & - & 28.2 & 1.9 \\
\hline Discoaster calcaris & - & - & 109.4 & 6.7 \\
\hline Gephyrocapsa caribbeanica & 25.2 & 1.7 & - & - \\
\hline Rhabdosphaera claviger & 52.4 & 3.1 & - & - \\
\hline Amaurolithus delicatus & 109.4 & 6.7 & 67.7 & 3.8 \\
\hline Pseudoemiliania lacunosa & 67.7 & 3.8 & 4.9 & 0.3 \\
\hline Rhabdosphaera longistylis & 13.4 & 0.9 & - & - \\
\hline Gephyrocapsa oceanica & 23.9 & 1.6 & - & - \\
\hline Discoaster pentaradiatus & - & - & 36.2 & 2.4 \\
\hline Rhabdosphaera procera & - & - & 10.7 & 0.9 \\
\hline Reticulofenestra pseudoumbilica & - & - & 63.9 & 3.6 \\
\hline Discoaster quinqueramus & - & - & 100.0 & 5.4 \\
\hline Ceratolithus rugosus & 93.2 & 5.1 & 16.4 & 1.1 \\
\hline Triquetrorhabdulus rugosus & - & - & 90.4 & 4.9 \\
\hline Discoaster surculus & 109.4 & 6.7 & 36.2 & 2.4 \\
\hline Discoaster tamalis & 66.2 & 3.7 & 41.9 & 2.7 \\
\hline Amaurolithus tricorniculatus & 101.3 & 5.6 & 88.7 & 4.8 \\
\hline Discoaster variabilis s.1. & - & - & 41.9 & 2.7 \\
\hline
\end{tabular}

Note: Ages of first appearance datums (FAD) and last appearance datums (LAD) are given in Ma, rounded to the nearest decimal. All depth/age calculations are for Hole 762B.

Table 2. Comparison of ages of calcareous nannofossil datums.

\begin{tabular}{|c|c|c|c|c|}
\hline & \multicolumn{2}{|c|}{ FAD (Ma) } & \multicolumn{2}{|c|}{ LAD (Ma) } \\
\hline & $\begin{array}{c}\text { Previous } \\
\text { work }\end{array}$ & $\begin{array}{l}\text { This } \\
\text { study }\end{array}$ & $\begin{array}{c}\text { Previous } \\
\text { work }\end{array}$ & $\begin{array}{l}\text { This } \\
\text { study }\end{array}$ \\
\hline Sphenolithus abies/S, neoabies & - & - & 3.5 & 3.4 \\
\hline Ceratolithus acutus & 5.0 & 5.4 & 4.6 & 4.8 \\
\hline Amaurolithus amplificus & 5.9 & 6.7 & 5.6 & 5.1 \\
\hline Discoaster asymmetricus & 4.1 & 4.0 & 2.2 & - \\
\hline Discoaster blackstockae & - & 6.3 & - & 5.4 \\
\hline Discoaster brouweri & - & - & 1.9 & 1.9 \\
\hline Discoaster calcaris & - & - & - & 6.7 \\
\hline Gephyrocapsa caribbeanica & 1.74 & 1.7 & - & - \\
\hline Rhabdosphaera claviger & - & 3.1 & - & - \\
\hline Amaurolithus delicatus & 6.5 & 6.7 & 3.7 & 3.8 \\
\hline Pseudoemiliania lacunosa & 3.4 & 3.8 & 0.47 & 0.3 \\
\hline Rhabdosphaera longistylis & - & 0.9 & - & - \\
\hline Gephyrocapsa oceanica & 1.68 & 1.6 & - & - \\
\hline Discoaster pentaradiatus & - & - & 2.4 & 2.4 \\
\hline Rhabdosphaera procera & - & - & - & 0.9 \\
\hline Reticulofenestra pseudoumbilica & - & - & 3.5 & 3.6 \\
\hline Discoaster quinqueramus & 8.2 & - & 5.6 & 5.4 \\
\hline Ceratolithus rugosus & 4.5 & 5.1 & - & 1.1 \\
\hline Triquetrorhabdulus rugosus & 14.0 & - & 5.0 & 4.9 \\
\hline Discoaster surculus & - & 6.7 & 2.4 & 2.4 \\
\hline Discoaster tamalis & 3.8 & 3.7 & 2.6 & 2.7 \\
\hline Amaurolithus tricorniculatus & 6.0 & 5.6 & 3.7 & 4.8 \\
\hline Discoaster variabilis s.l. & - & - & 2.9 & 2.7 \\
\hline
\end{tabular}

Note: FADs/LADs complied by Berggren et al. (1985b) are shown under "previous work." Original literature references for these ages may be found in the papers listed in Berggren et al. (1985b). All ages shown under "this study" are for Hole 762B.

Berggren et al. (1985b) for the Neogene. These previously published ages are shown in Table 2 for comparison with our results. In comparing one study to another, apparent diachroneity of the FAD/LAD of a species may be caused by true differences in times of first appearance/extinction of the species, but may also result simply from differing taxonomic concepts, biostratigraphic inaccuracies, changes in sedimentation rates, or use of different time scales for calculations. An accurate assessment of the reliability (the synchroneity and/or diachroneity) of FADs/LADs over a latitudinal range depends on a data base consisting of a large number of age assignments. Caution should be used in judging the degree of a species' synchroneity/diachroneity until sufficient well-documented ages from many different regions are available. We believe the age dates presented here will be a significant addition to the growing data base of ordered evolutionary events on which biomagnetochronology is based.

\section{SUMMARY}

The integration of biostratigraphy and magnetostratigraphy is essential to the development of a worldwide biomagnetochronology. During Leg 122 drilling on the Exmouth Plateau, we encountered an almost complete Cenozoic stratigraphic sequence containing well-preserved nannofossils at Site 762. Magnetostratigraphic analyses were also obtained on the same cores, which provided an opportunity to investigate the biomagnetostratigraphy of late Miocene-Quaternary nannofossils at Site 762. FADs/LADs for 23 nannofossil species have been calculated. FADs and/or LADs for six of these species have not previously been presented.

Data from different oceans, different latitudes, and from different microfossil groups are necessary for the establishment of a truly reliable global biomagnetochronology. Relatively little biomagnetochronologic work has been done previously in the Indian Ocean, making the source of the age dates presented here important by itself. The new age dates, and the complementary information on previously published age dates, will add to the growing refinement of the biomagnetochronologic time scale.

\section{ACKNOWLEDGMENTS}

This work was supported by a grant to WGS from the NSF/JOI United States Science Program. The U.S. Science Support Program associated with the Ocean Drilling Program is sponsored by the National Science Foundation and the Joint Oceanographic Institutions, Inc. Any opinions, findings, and conclusions or recommendations expressed in this publication are those of the authors and do not necessarily reflect the views of the National Science Foundation, the Joint Oceanographic Institutions, Inc., or Texas A\&M University.

\section{REFERENCES}

Aubry, M.-P., Berggren, W. A., Kent, D. V., Flynn, J. J., Klitgord, K. D., Obradovich, J. D., and Prothero, D. R., 1988. Paleogene geochronology: an integrated approach. Paleoceanography, 3:707-742.

Aubry, M.-P., Hailwood, E. A., and Townsend, H. A., 1986. Magnetic and calcareous-nannofossil stratigraphy of the lower Palaeogene formations of the Hampshire and London basins. J. Geol. Soc. London, 143:729-735.

Backman, J., and Shackleton, N. J., 1983. Quantitative biochronology of Pliocene and early Pleistocene calcareous nannofossils from the Atlantic, Indian and Pacific oceans. Mar. Micropaleontol., 8:141-170,

Berggren, W. A., Aubry, M.-P., and Hamilton, N., 1983. Neogene magnetobiostratigraphy of Deep Sea Drilling Project Site 516 (Rio Grande Rise, South Atlantic). In Barker, P. F., Carlson, R. L., and Johnson, D. A., et al., Init. Repts. DSDP, 72: Washington (U.S. Govt. Printing Office), 675-713.

Berggren, W. A., Kent, D. V., and Flynn, J. J., 1985a. Jurassic to Paleogene: Part 2. Paleogene geochronology and chronostratigraphy. In Snelling, N. J. (Ed.), The Chronology of the Geological Record. Geol. Soc. London Mem., 10:141-195.

Berggren, W. A., Kent, D. V., and Van Couvering, J. A., 1985b. The Neogene: Part 2. Neogene geochronology and chronostratigraphy. In Snelling, N. J. (Ed.), The Chronology of the Geological Record. Geol. Soc. London Mem., 10:211-260.

Berggren, W. A., and van Couvering, J. A., 1978. Biochronology. In Gohee, G. V., Glaessner, M. F., and Hedberg, H. D. (Eds.), Contributions to the Geologic Time Scale. AAPG, 39-55. 
Bukry, D., 1973. Low-latitude coccolith biostratigraphic zonation. In Edgar, N. T., Saunders, J. B., et al., Init. Repts. DSDP, 15: Washington (U.S. Govt. Printing Office), 685-703.

1975. Coccolith and silicoflagellate stratigraphy, northwestern Pacific Ocean, Deep Sea Drilling Project Leg 32. In Larson, R. L., Moberly, R., et al., Init. Repts. DSDP, 32: Washington (U.S. Govt. Printing Office), 677-701.

Dowsett, H. J., 1989. Application of the graphic correlation method to Pliocene marine sequences. Mar. Micropaleontol., 14:3-32.

Gartner, S., 1973. Absolute chronology of the late Neogene calcareous nannofossil succession in the Equatorial Pacific. Geol. Soc. Am. Bull., 84:2021-2034.

Haq, B. U., 1984. Jurassic to Recent nannofossil biochronology: an update. In Haq, B. U. (Ed.), Nannofossil Biostratigraphy. Benchmark Papers in Geology: Stroudsburg, PA (Hutchinson Ross), $358-378$.

Haq, B. U., and Takayama, T., 1984. Neogene calcareous nannoplankton datum planes and their correlation to magnetostratigraphy. In Ikebe, N., and Tsuchi, R. (Eds.), Pacific Neogene Datum Planes: Tokyo (Univ. Tokyo Press), 27-33.

Haq, B. U., Berggren, W. A., and van Couvering, J. A., 1977. Corrected age of the Pliocene/Pleistocene boundary. Nature, 269:483-488.

Haq, B. U., Hardenbol, J., and Vail, P. R., 1987. Chronology of fluctuating sea levels since the Triassic. Science, 235:11561167.

Haq, B. U., Hardenbol, J., and Vail, P. R., 1988a. Mesozoic and Cenozoic chronostratigraphy and cycles of sea-level change. In Wilgus, C., et al., (Eds.), Sea-Level Change-An Integrated Approach. Soc. Econ. Paleontol. Mineral. Spec. Publ., 42:71108.

Haq, B. U., von Rad, U., and the ODP Leg 122 Scientific Party, 1988b. ODP Leg 122 looks at Exmouth Plateau. Geotimes, 33:10-13.

Hills, S. J., and Thierstein, H. R., 1989. Plio-Pleistocene calcareous plankton biochronology. Mar. Micropaleontol., 14:67-96.

Hsü, K. J., Percival, S. F., Wright, R. C., and Petersen, N. P., 1984. Numerical ages of magnetostratigraphically calibrated biostratigraphic zones. In Hsü, K. J., La Brecque, J. L., et al., Init. Repts. DSDP, 73: Washington (U.S. Govt. Printing Office), 623-635.

Lowrie, W., Alvarez, W., Napoleone, G., Perch-Nielsen, K., Premoli Silva, I., and Toumarkine, M., 1982. Paleogene magnetic stratigraphy in Umbrian pelagic carbonate rocks: the Contessa sections, Gubbio. Geol. Soc. Am. Bull., 93:414-432.

Martini, E., 1971. Standard Tertiary and Quaternary calcareous nannoplankton zonation. In Farinacci, A. (Ed.), Proc. 2nd Planktonic Conf. Roma: Rome (Ed. Technosci.), 2:739-785.

Monechi, S., and Thierstein, H. R., 1985. Late Cretaceous-Eocene nannofossil and magnetostratigraphic correlations near Gubbio, Italy. Mar. Micropaleontol., 9:419-440.

Okada, H., and Bukry, D., 1980. Supplementary modification and introduction of code numbers to the low-latitude coccolith biostratigraphic zonation (Bukry, 1973; 1975). Mar. Micropaleontol., $5: 321-325$.

Poore, R. Z., Tauxe, L., Percival, S. F., Jr., LaBrecque, J. L., Wright, R., Peterson, N. P., Smith, C. C., Tucker, P., and Hsü, K. J., 1984. Late Cretaceous-Cenozoic magnetostratigraphic and biostratigraphic correlations for the South Atlantic Ocean, Deep Sea Drilling Project Leg 73. In Hsü, K. J., La Brecque, J. L., et al., Init. Repts. DSDP, 73: Washington (U.S. Govt. Printing Office), $645-655$.

Ryan, W.B.F., Cita, M. B., Dreyfus, R., Rawson, M., Burkle, L. H., and Saito, T., 1974. A paleomagnetic assignment of Neogene slope boundaries and the development of isochronous datum planes between the Mediterranean, the Pacific, and Indian Oceans in order to investigate the response of the world ocean to the Mediterranean "salinity crisis." Riv. Ital. Paleontol. Stratigr., 80:631-688.

Shackleton, N. J., and Shipboard Scientific Party, 1984. Accumulation rates in Leg 74 sediments. In Moore, T. C., Jr., Rabinowitz, P. D., et al., Init. Repts. DSDP, 74: Washington (U.S. Govt. Printing Office), 621-637.

Tauxe, L., Tucker, P., Petersen, N. P., and LaBrecque, J. L., 1984. Magnetostratigraphy of Leg 73 sediments. In Hsü, K. J., LaBrecque, J. L., et al., Init. Repts. DSDP, 73: Washington (U.S. Govt. Printing Office), 609-621.
Weaver, P.P.E., Backman, J., Baldauf, J. G., Bloemendal, J., Manivit, H., Miller, K. G., Pokras, E. M., Raymo, M. E., Tauxe, L., Valet, J.-P., Chepstow-Lusty, A., and Olafsson, G., 1989. Biostratigraphic synthesis: Leg 108, eastern equatorial Atlantic. In Ruddiman, W., Sarnthein, M., et al., Proc. ODP, Sci. Results, 108: College Station, TX (Ocean Drilling Program), 455-462.

Wei, W., and Wise, S. W., Jr. 1989. Paleogene calcareous nannofossil magnetobiochronology: results from South Atlantic DSDP Site 516. Mar. Micropaleontol., 14:119-152.

Date of initial receipt: 3 September 1990

Date of acceptance: 4 March 1991

Ms 122B-164

\section{APPENDIX}

Positions of FOs and/or LOs of calcareous nannofossil species within chrons in Hole 762B. Refer to Figure 2 for polarity and chron illustrations.

Sphenolithus abies/S. neoabies

LO: Within lowest Chron C2A-N interval

Ceratolithus acutus

FO: Base of lowest Chron C3-R interval

LO: Within mid Chron C3-R interval

Amaurolithus amplificus

FO: Chron C3A-C4 boundary

LO: Within lowest $\mathrm{C} 3-\mathrm{N}$ interval

Discoaster asymmetricus

FO: Just below top of uppermost $\mathrm{C} 3-\mathrm{N}$ interval

Discoaster blackstockae

FO: Lower part of middle C3A-N interval

LO: Lower part of lowest C3-R interval

Discoaster brouweri

LO: Base of $\mathrm{C} 2-\mathrm{N}$ interval

Discoaster calcaris

LO: Chron C3A-C4 boundary

Gephyrocapsa caribbeanica

FO: Chron $\mathrm{C} 1-\mathrm{C} 2$ boundary

Rhabdosphaera claviger

FO: Top of mid C3A-N interval

Amaurolithus delicatus

FO: Chron $\mathrm{C} 3 \mathrm{~A}-\mathrm{C} 4$ boundary

LO: Within lowest C2A-R interval

Pseudoemiliania lacunosa

FO: Within lowest C2A-R interval

LO: Middle of upper Cl-N interval

Rhabdosphaera longistylis

FO: Base of mid Cl-N interval

Gephyrocapsa oceanica

FO: Lower part of lowest C1-R interval

Discoaster pentaradiatus

LO: Lower part of C2-R interval

Rhabdosphaera procera

LO: Base of uppermost $\mathrm{C} 1-\mathrm{N}$ interval

Reticulofenestra pseudoumbilica

LO: Upper part of lowest CA-R interval

Discoaster quinqueramus

LO: Chron $\mathrm{C} 3-\mathrm{C} 3 \mathrm{~A}$ boundary

Ceratolithus rugosus

FO: Within lowest $\mathrm{C} 3-\mathrm{N}$ interval

LO: Within lowest C1-R interval

Triquetrorhabdulus rugosus

LO: At top of lowest C3-R interval

Discoaster surculus

FO: Chron C3A-C4 boundary

LO: Lower part of $\mathrm{C} 2-\mathrm{R}$ interval

Discoaster tamalis

FO: Within lowest C2A-R interval

LO: Within uppermost C2A-N interval

Amaurolithus tricorniculatus

FO: Base of uppermost C3A-N interval

LO: Within mid C3-R interval

Discoaster variabilis s.l.

LO: Within uppermost C2A-N interval 